〔Med. Entomol. Zool. Vol. 56 No. 2 p. 65-71 2005]

\title{
Culicid and Chaoborid flies (Diptera: Culicidae and Chaoboridae) attracted to a CDC miniature frog call trap at Iriomote Island, the Ryukyu Archipelago, Japan
}

\author{
Takako Toma ${ }^{1), 2)}$, Ichiro Mryagi ${ }^{1), 3)}$, Yukiko HigA ${ }^{1)}$, \\ Takao OKAzAWA ${ }^{4)}$ and Hitoshi SASAKI ${ }^{5)}$ \\ ${ }^{1)}$ Laboratory of Medical Zoology, School of Health Science, Faculty of Medicine, \\ University of the Ryukyus, Nishihara, Okinawa, 903-0215 Japan \\ ${ }^{2)}$ Center for Asia-Pacific Island Studies, Universtiy of the Ryukyus, Senbaru, 1, \\ Nishihara, Okinawa, 903-0213 Japan \\ ${ }^{3)}$ Laboratory of Mosquito Systematics of Southeast Asia and South Pacific, c/o Ocean \\ Health Corporation, 4-21-11 Iso, Urasoe, Okinawa, 901-2132 Japan \\ 4) International Student Center, Kanazawa University, Kakuma-machi, \\ Kanazawa, Ishikawa, 920-1192 Japan \\ 5) Laboratory of Entomology, Rakuno Gakuen University, Ebetsu, Hokkaido, 069-8501 Japan
}

(Received: 18 October 2004; Accepted: 17 January 2005)

\begin{abstract}
Mosquito collections were made at two foothill sites of Iriomote Island, the Ryukyu Archipelago, Japan, by modified CDC miniature light traps with a frog call CD player from June 12 to 18,2004 . A total of 777 and 257 female Diptera was collected at sites 1 and 2, respectively. Among them, 4 haematophagous species were predominant at sites 1 and 2-Uranotaenia macfarlanei with 580 (74.6\%) and 193 (75.1\%) individuals respectively, Ur. yaeyamana 19 (2.4\%) and 27 (10.5\%), and Corethrella nippon 106 (13.6\%) and 20 (7.8\%) which is a new record for Iriomote Island, and Mimomyia luzonensis with $39(5.0 \%)$ individuals was predominant at site 1 . The females of these species collected by the traps fed easily on a frog, Rana limnocharis exposed in the cage. The results demonstrated clearly that frog call is the primary stimulus in guiding these Culicine and Chaoborine flies in their search for host animals in nature.
\end{abstract}

Key words: frog call, Culicidae, Chaoboridae, feeding behavior, Japan

\section{INTRODUCTION}

McKeever (1977) reported for the first time that the females of the chaoborid gnats Corethrella brakeleyi and C. wirthi were attracted to the frog calls that were broadcasted from a cassette player. $\mathrm{He}$ collected successfully a large sample of the female Corethrella by a modified CDC miniature light trap placed close to the cassette player in Statesboro, Georgia, USA (McKeever and Hartberg, 1980). The genus Corethrella is closely related to the mosquito biologically and morphological- ly, and had been treated as a subfamily Chaoborinae of the family Culicidae (Edwards, 1932). Stone (1956) elevated the subfamily Chaoborinae to a separate family Chaoboridae. The females of the genus Corethrella are known to feed readily on animals, especially frogs in the field (Williams and Edman, 1968; Miyagi, 1974; MacKeever, 1977). MacKeever and Hartberg (1980) reported also 9 female mosquitoes together with 566 Corethrella collected by the frog call trap during one 30min. test period in Statesboro, Georgia, USA, but these mosquitoes were not identified as to species. 
To determine whether mosquito and Corethrella flies occurring in the Ryukyu Archipelago, Japan, are attracted to frog calls, which were broadcasted from a CD player in the foothill areas of Iriomote Island. Diptera were collected by the CDC miniature traps hung close to the player. The feeding behavior of some mosquitoes and Corethrella attracted to the frog calls is discussed briefly.

\section{Materials And Methods}

Iriomote Island $\left(24^{\circ} 23^{\prime} \mathrm{N}, 123^{\circ} 45^{\prime} \mathrm{E}\right)$ has an area of $284,44 \mathrm{~km}^{2}$ and is located approximately $700 \mathrm{~km}$ south of Okinawa Islands, with about $90 \%$ covered with thick forests (Fig. 1). The climate is subtropical, having an average annual temperature of $23.2^{\circ} \mathrm{C}$ (the coldest $15.0^{\circ} \mathrm{C}$ in February, hottest $30.1^{\circ} \mathrm{C}$ in July) and average annual rainfall of $1,912 \mathrm{~mm}$ according to the 1999 census. The collections were made over 5 nights between June 12 and 18, 2004 in Iriomote Island, Ryukyu Archipelago, Japan. Two sites were selected at foothill areas of Komi for observation. Site 1 is a mountainous area with paddy fields, along the Fukari River, while site 2 is the backyard of the Iriomote Wildlife Center, about $200 \mathrm{~m}$ from site 1 .

A set of CD (Compact Disc) player and CDC miniature light trap without a bulb (McKeener and Hartberg, 1980) was hung close on a tree, about $1.5 \mathrm{~m}$ above the

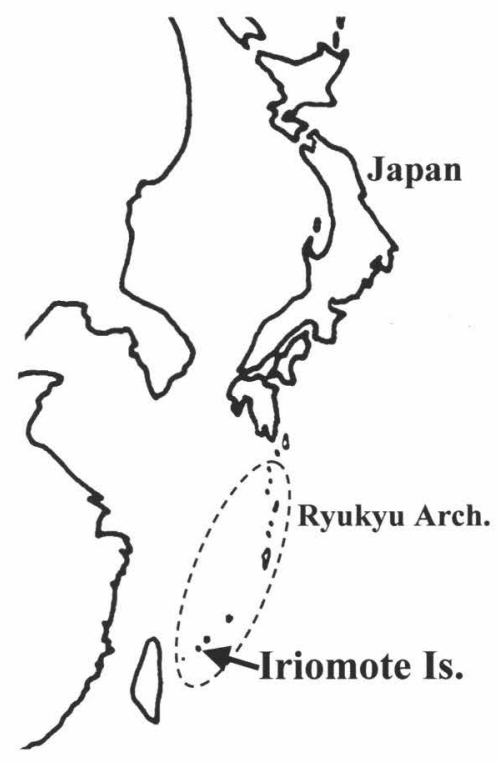

Fig. 1. Map of Japan and the Ryukyu Archipelago showing Iriomote Island.

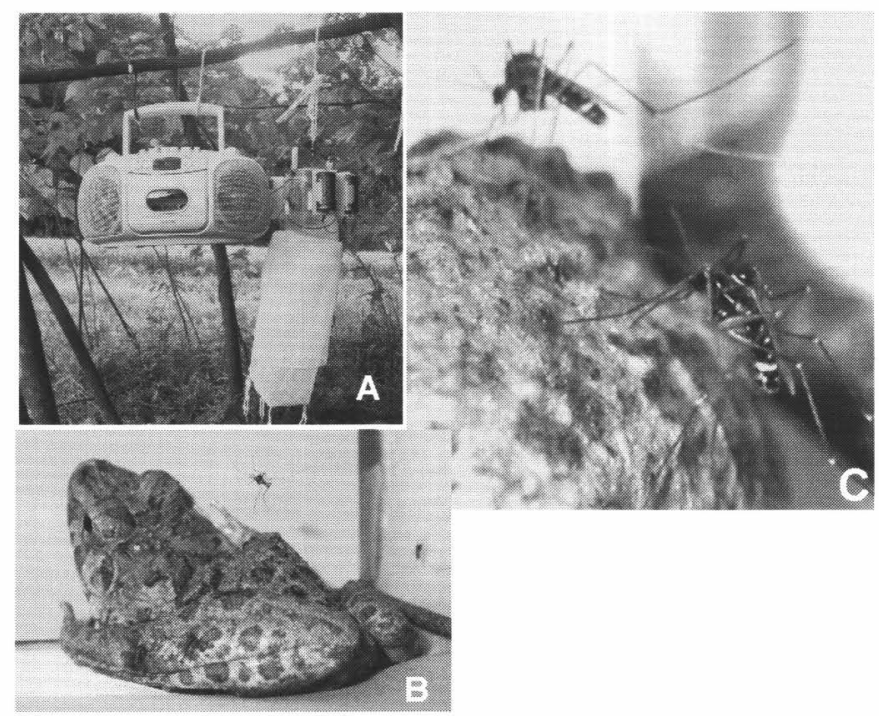

Fig. 2. A, CDC miniature light trap and compact disc player for collecting Diptera; B, A frog, Rana limnocharis, exposed to Culicine and Chaoborine flies in a cage; C, Uranotaenia macfarlanei feeding on a frog. 
ground (Fig. 2A). The calls of 8 common species of frogs (Hyla hallowellii, Rhacophorus owstoni, Chirixalus eiffingeri, Buergeria japonica, Microhyla ornate, Rana limnocharis, $R$. narina and $R$. psaltes) were recorded in a compact disc (Kabaya and Maeda, 2002) and used in the field collection. Broadcasting of the calls took place continuously overnight, from $7: 00$ p.m. to 7:00 a.m. the next morning. As control, collections by the same type of trap without the broadcasting of frog calls and a bulb, were made at the sites, operated about $10 \mathrm{~m}$ apart from the $\mathrm{CD}$ player, during the same period. Two day-time collections were also made from 8:00 a.m. to $5: 00$ p.m. at site 2 where the frog call traps were carried out. The flies absorbed into the bag attached on the traps were sorted and identified under a binocular microscope. Culicine and Chaoborine flies were identified to species following Miyagi (1975), Miyagi and Toma (1980), Tanaka et al. (1979) and Toma and Miyagi (1986); other Diptera were identified to family and genus. The sex of the Culicidae, Chaoboridae, Sergentomya sp. and Culicoides sp. were distinguished but other dipterans were not distinguished.

In order to know the host preferences of the Culicid and Chaoborid flies attracted to the frog-call traps, biting tests were undertaken outdoors. A frog, R. limnocharis, captured around the study site was

Table 1. Diptera collected by frog call and control traps at site 1, Fukari River, Komi, Iriomote Island, Okinawa, June 12-18, 2004.

\begin{tabular}{|c|c|c|c|c|c|c|c|c|c|c|c|c|c|}
\hline \multirow{2}{*}{ Names of flies } & \multicolumn{2}{|c|}{ June $12-13$} & \multicolumn{2}{|c|}{ June $14-15$} & \multicolumn{2}{|c|}{ June $15-16$} & \multicolumn{2}{|c|}{ June 16-17 } & \multicolumn{2}{|c|}{ June $17-18$} & \multicolumn{3}{|c|}{ Total } \\
\hline & Frog* & $\mathrm{C}^{* *}$ & Frog & $\mathrm{C}$ & Frog & $\mathrm{C}$ & Frog & $\mathrm{C}$ & Frog & $\mathrm{C}$ & Frog & $\%$ & $\mathrm{C}$ \\
\hline \multicolumn{14}{|l|}{ Culicidae } \\
\hline Ur. macfarlanei & 108 & 1 & 137 & 0 & 110 & 0 & 93 & 0 & 132 & 0 & 580 & 74.6 & 1 \\
\hline Ur. yaeyamana & 4 & 0 & 3 & 0 & 6 & 0 & 3 & (1) & 3 & 0 & 19 & 2.4 & (1) \\
\hline Ur. ohamai & 1 & 0 & 0 & 0 & 1 & 0 & 0 & 0 & 0 & 0 & 2 & 0.3 & 0 \\
\hline Mi. luzonensis & 16 & 0 & 6 & 0 & 6 & 0 & 3 & 0 & 8 & 0 & 39 & 5.0 & 0 \\
\hline Ve. iriomotensis & 0 & 0 & 0 & 0 & 0 & 0 & 0 & 1 & 0 & 0 & 0 & & 1 \\
\hline Ve. atriisimilis & 0 & 0 & 0 & 0 & 0 & 0 & 0 & (1) & 0 & 0 & 0 & & (1) \\
\hline Ae. vexans nipponii & 0 & 0 & 0 & 0 & 0 & 0 & 0 & 0 & 1 & 0 & 1 & & 0 \\
\hline Ae. riversi & 0 & 1 & 0 & 0 & 0 & 0 & 0 & 0 & 0 & 0 & 0 & & 1 \\
\hline Cx. bitaeniorynchus & 0 & 0 & 1 & 0 & 0 & 1 & 0 & 0 & 0 & 0 & 1 & & 1 \\
\hline Cx.fuscocephala & 0 & 0 & 0 & 0 & 0 & 0 & 0 & 0 & 2 & 0 & 2 & & 0 \\
\hline Lu. halifaxii & 0 & 0 & 0 & 0 & 0 & 1 & 0 & 0 & 0 & 0 & 0 & & 1 \\
\hline Ar. subalbatus & 0 & 0 & 0 & 0 & 0 & 0 & 0 & (1) & 0 & 0 & 0 & & $(1)$ \\
\hline \multicolumn{14}{|l|}{ Chaoboridae } \\
\hline C. nippon & 4 & 0 & 16 & 0 & 12 & 0 & 19 & 0 & 55 & 0 & 106 & 13.6 & 0 \\
\hline C. urumense & 0 & 0 & 0 & 0 & 1 & 0 & 0 & 0 & 4 & 0 & 5 & 0.6 & 0 \\
\hline \multicolumn{14}{|l|}{ Other Diptera } \\
\hline Mycetophailidae & 1 & 0 & 3 & 1 & 0 & 1 & 0 & 0 & 0 & 0 & 4 & & 2 \\
\hline Tipulidae & 0 & 0 & 0 & 2 & 0 & 1 & 0 & 0 & 0 & 0 & 0 & & 3 \\
\hline Cecidomyidae & 3 & 0 & 6 & 9 & 0 & 6 & 0 & 5 & 0 & 0 & 9 & 1.2 & 20 \\
\hline Psychodidae & 1 & 0 & 0 & 5 & 0 & 0 & 0 & 5 & 0 & 0 & 1 & & 10 \\
\hline Sergentomyia sp. & 0 & $(2)$ & 0 & 0 & 0 & 1 & 0 & 0 & 0 & 0 & 0 & & $1(2)$ \\
\hline Culicoides sp. & 2 & 0 & 0 & 0 & 0 & 0 & 0 & 0 & 0 & 0 & 2 & & 0 \\
\hline Sphaeroceridae & 1 & 0 & 5 & 5 & 0 & 0 & 0 & 8 & 0 & 0 & 6 & 0.8 & 13 \\
\hline Total & & & & & & & & & & & 777 & 100 & $54(5)$ \\
\hline
\end{tabular}


Table 2. Diptera collected by frog call and control traps at site 2, Iriomote Wildlife Center of Iriomote Island, Okinawa, June 12-17, 2004.

\begin{tabular}{|c|c|c|c|c|c|c|c|c|c|c|c|c|c|}
\hline \multirow{2}{*}{ Names of flies } & \multicolumn{2}{|c|}{ June $12-13$} & \multicolumn{2}{|c|}{ June $13-14$} & \multicolumn{2}{|c|}{ June $14-15$} & \multicolumn{2}{|c|}{ June $15-16$} & \multicolumn{2}{|c|}{ June $16-17$} & \multicolumn{3}{|c|}{ Total } \\
\hline & Frog* & $\mathrm{C}^{* *}$ & Frog & $\mathrm{C}$ & Frog & $\mathrm{C}$ & Frog & $\mathrm{C}$ & Frog & $\mathrm{C}$ & Frog & $\%$ & $\mathrm{C}$ \\
\hline \multicolumn{14}{|l|}{ Culicidae } \\
\hline Ur. macfarlanei & 49 & 0 & 23 & 0 & 57 & 0 & 32 & 0 & 32 & 0 & 193 & 75.1 & 0 \\
\hline Ur. yaeyamana & 4 & 0 & 1 & 0 & 8 & 1 & 3 & 0 & 11 & 0 & 27 & 10.5 & 1 \\
\hline Ur. ohamai & 2 & 0 & 0 & 0 & 0 & 0 & 0 & 0 & 1 & 0 & 3 & 1.2 & 0 \\
\hline Ae. riversi & 1 & 0 & 0 & 0 & 0 & 0 & 0 & 0 & 0 & 0 & 1 & 0.4 & 0 \\
\hline \multicolumn{14}{|l|}{ Chaoboridae } \\
\hline C. nippon & 5 & & 0 & 0 & 3 & 0 & 4 & 0 & 8 & 0 & 20 & 7.8 & 0 \\
\hline \multicolumn{14}{|l|}{ Other Diptera } \\
\hline Mycetophailidae & 0 & 0 & 0 & 0 & 2 & 0 & 0 & 0 & 0 & 0 & 2 & & 0 \\
\hline Cecidomyiade & 6 & 0 & 1 & 4 & 2 & 3 & 0 & 11 & 0 & 5 & 9 & & 23 \\
\hline Psychodidae & 0 & 0 & 0 & 0 & 0 & 0 & 0 & 3 & 0 & 1 & 0 & & 4 \\
\hline Sergentomyia sp. & 0 & 0 & 0 & 1 & 0 & (1) & 0 & 0 & 0 & 0 & 0 & & $1(1)$ \\
\hline Sphaeroceridae & 2 & 0 & 0 & 0 & 0 & 3 & 0 & 0 & 0 & 1 & 2 & & 4 \\
\hline Total & & & & & & & & & & & 257 & 100 & $33(1)$ \\
\hline
\end{tabular}

* Frog: Trap with frog call. ** C: Control trap without frog call.

( ): Number in parentheses shows male.

Collections were made usually from $7: 00$ p.m. to $7: 00$ a.m.

exposed to the flies collected by the frog call traps in a cage $(20 \times 30 \times 20 \mathrm{~cm})$ for several hours from 24:00 to 06:00 (Fig. 2B). This test was repeated three times. One test was carried out in the daytime from $08: 00$ to $17: 00$. Feeding activities of the flies in the cage were observed and photographed. The number of engorged females was counted.

\section{RESUlts}

A total of 777 and 257 Diptera was collected by frog call CDC traps at sites 1 and 2 , respectively, in Komi, Iriomote Island, over 5 nights from June 12 to 18,2004 (Tables 1 and 2). They were all females, comprising 12 species of the family Culicidae [Uranotaenia (Uranotaenia) macfarlanei Edwards, Ur. (Pseudoficalbia) yaeyamana Tanaka et al., Ur. (Pfc.) ohamai Tanaka et al., Mimomyia (Etorleptomyia) luzonensis (Ludlow), Verrallina iriomotensis (Tanaka and Muzusawa), Ve. atriisimilis (Tanaka and Mizusawa), Aedes (Aedimorphus) vexans nipponii (Theobald), Ae. (Stegomyia) riversi Bohart and Ingram,
Culex (Culex) bitaeniorhynchus Giles, Cx. (Cux.) fuscocephala Theobald, Lutzia (Metalutzia) halifaxii (Theobald) and Armigeres (Armigeres) subalbatus (Coquillett)], and 2 species of the family Chaoboridae [C. nippon Miyagi and $C$. urumense Miyagi]. The predominant culicid species at sites 1 and 2 were Ur. macfarlanei with 580 (74.6\%) and $193(75.1 \%)$ individuals, respectively, and Ur. yaeyamana 19 (2.4\%) and 27 (10.5\%). Mimomyia luzonensis 39 $(5.0 \%)$ was predominant only at site 1 . A few Ur. ohamai were collected at both sites and $C x$. fuscocephala at site 1 . Other mosquitoes collected comprised only one female or male. Of the two chaoborid species, C. nippon with 106 (13.6\%) and 20 $(7.8 \%)$ individuals, was collected at sites 1 and 2 , respectively, and $C$. urumense with $5(0.6 \%)$ individuals at site 1 . Other Dipteran comprised Mycetophailidae, Tipulidae, Cecidomyidae, Psychodidae, Sphaeroceridae, and Culicoides sp. which were small in number, and miscellaneous taxa including males.

In the control traps (Tables 1 and 2), a total of 54 and 33 Diptera was collected at 
Table 3. Culicine and Chaoborine flies fed on frog Rana limnocharis in a cage.

\begin{tabular}{|c|c|c|c|c|c|c|c|c|}
\hline \multirow{2}{*}{ Names of flies } & \multicolumn{2}{|c|}{ Test $1(24: 00-06: 00)$} & \multicolumn{2}{|c|}{ Test $2(08: 00-17: 00)$} & \multicolumn{2}{|c|}{ Test $3(24: 00-06: 00)$} & \multicolumn{2}{|c|}{ Total } \\
\hline & No. exam.* & No. fed** & No. exam. & No. fed & No. exam. & No. fed & No. exam. & No. fed \\
\hline Mi. luzonensis & 4 & 2 & 0 & 0 & 3 & 2 & 7 & 4 \\
\hline Ur. macfarlanei & 38 & 24 & 55 & 11 & 34 & 6 & 127 & 41 \\
\hline Ur. yaeyamana & 2 & 0 & 1 & 1 & 3 & 0 & 6 & 1 \\
\hline Cx. fuscocephala & 0 & 0 & 0 & 0 & 2 & 0 & 2 & 0 \\
\hline C. nippon & 13 & 0 & 6 & 0 & 32 & 2 & 51 & 2 \\
\hline
\end{tabular}

* Numbers of examined flies collected by the frog call traps and exposed to the frog in a cage $(30 \times 20 \times$ $20 \mathrm{~cm}$ ).

** Number of flies fed on frog.

( ): Times exposed to a frog.

sites 1 and 2, respectively. Most of them were non-biting flies - Cecidomyidae (20 at sites 1 and 23 at site 2), and Sphaeroceridae (13 at site 1$)$ were predominant. Only one female or male of Ur. macfarlanei, Ve. iriomotensis, Ve atrisimilis, Ae. riversi, Cx. bitaeniorynchus, Lu. halifaxii and Ar. subalbatus were trapped. One female and 2 males of Sergentomyia sp. at site 1 , and 1 female and 1 male at site 2 were also collected in the control traps. No Chaoboridae were trapped.

A total of 51 female culicine and chaoborine flies collected by frog call traps was exposed to a frog in a cage for several hours, twice at night and once during the day (Table 3 ). The cages covered with dark wet paper were placed in a small outdoor shed. As soon as being placed with the frog, Ur. macfarlanei showed interest, and some alit on the dorsal part of the frog and began to feed (Fig. 2C). Some alit on the floor behind the hind legs of the frog and walked slowly toward it. Other flies in the cage were inactive and showed no desire to feed under a direct light, and it was difficult to observe their feeding. Several hours after exposure to the frog in the dark, Ur. macfarlanei (41/127 females), Mi. luzonensis (4/7), Ur. yaeyamana $(1 / 6)$ and C. nippon (2/51) fed on the frog, with reddish blood in their stomachs. Two females of Cx. fuscocephala did not feed on the frog in the cage. No flies were collected by the frog call traps operated during the day.

\section{Discussion}

It is well known that only the female mosquitoes bite, and body odour and carbon dioxide carried on the wind, stimulate the sense receptors on the antennae and palpus of female mosquitoes, alerting them to the presence of a host (Clements, 1992). Temperature and humidity gradients also may play an important part in the final descent on the host. These stimuli may be similar in all mosquitoes that bite warm-blooded animals, though the relative importance of different classes of stimuli may vary with the species of mosquito, and the threshold of stimulus necessary to elicit a response may also vary, since it is well known that different species of mosquitoes show characteristic host preferences (Bates, 1949). So far as we are aware, there is little information on the importance of calls of host animals as the primary stimulus in guiding a mosquito in its search for blood meal. McKeever (1977) indicated for the first time that Corethrella flies were attracted to the calls of their host, tree frogs Hyla spp. in Georgia.

The mosquito fauna of the island is well studied and it is very rich; 59 species of 14 genera have been reported (Miyagi and Toma, 1980; Toma et al., 1983; Toma and Higa, 2004). However, our knowledge on the feeding habits of the mosquitoes in the island is limited. Twenty-six (44\%) of the 
59 species are zoophilic or anthoropophilic, collected readily by human-bait net traps, but others are unknown, except Toxorhynchites yaeyamae Bohart, Malaya genurostris Leicester and Topomyia yanbarensis Miyagi which are well-known as non-haematophagous mosquitoes. Some species of Uranotaenia and the subgenera Eumelanomyia and Lophoceraomyia of Culex are known to bite amphibians. Miyagi (1972) reported Cx. (Eum.) hayashii Yamada and Ur. (Psf.) novobscura Barraud collected in Nagasaki, mainland Japan, to feed on frogs, and Cx. (Lop.) infantulus Edwards on cold- and warm-blooded animals in the cages. Recently, Okudo et al. (2004), reported that Ochlerotratus (Geosuksea) baisasi Knight and Hull fed on a mudskipper (Periophthalmus argentilineatus Valenciences) in the mangrove forests of this island. However, there have been no studies on the feeding habits of the culicid and chaoborid flies attracted to calls of their host animals.

A considerable number of the females of Ur. macfarlanei, Ur. yaeymana, Mi. luzonensis and C. nippon was attracted to frog calls in the present study. Due to the broadcast of 9 species of frog calls continuously throughout the night, it is difficult to know which frog's call acted as the stimulus for each fly. In the control traps with no broadcasting, most of the flies trapped were non-biting, and no females of Ur. macfarlanei, Ur. yaeyamana, Mi. luzonensis and C. nippon came to the speaker.

Site 1 in the present study is a mountainous area with paddy fields where 3 species of Uranotaenia-Ur. (Psf.) novobscura novobscura Tanaka et al., Ur. (Ura.) annandalei Barraud and Ur. (Ura.) lateralis, other than Ur. macfalanei, Ur. yaeyamana and Ur. ohamai, and Culex (Eum.) hayashii, Cx. (Eum.) okinawae Bohart, Cx. (Lop.) cinctellus Edwards, Cx. (Lop.) infantulus, and Cx. (Lop.) bicornutus (Theobald)-were found by Miyagi and Toma (1980). The adults of these species are abundant in the vicinity of the larval habitats, such as dark recesses in the stream bank, including freshwater crab and tree holes. Although they were not attracted to the broadcasting of frog calls in the study, some of them may feed on amphibians in nature. Uranotaenia albescens Taylar and Culex (Lop.) sp. fed on a large green frog, Hyla caerulea (Shaw) in the Australian region (Marks, 1960) and Ur. lowii Theobald fed on a tree frog (Hyla cinerea) in Lousiana (Remington, 1945).

The larvae of Mi. luzonensis and Mi. elegans (Taylor) are found in paddy fields containing decaying vegetable matter in Iriomote Island. The feeding habits of $M i$. elegans in the island are unknown, but like Mi. luzonensis shown by the present study, Mi. elegans may be attracted to frog calls and feed on frog in nature. Mimomyia elegans was observed to feed on the introduced toad, Bufo marinus in Australia (Van Beurden, 1980).

Corethrella nippon is known to occur in Nagasaki, Amami Island (Miyagi, 1980) and Taiwan (Lien et al., 1998). The distribution record of this species in the Ryukyu Archipelago is new. The females of $C$. nippon were engorged with reddish or darkened stomach content, the blood presumably of vertebrate animals such as frogs (Miyagi, 1974; Lien et al., 1998). Only 5 females of $C$. urumense Miyagi were collected by the frog-call traps at site 1 which is the type locality of this species (Miyagi, 1975). They may feed on frog like C. nippon. McKeever (1977) and McKeever and Hartberg (1980), reported that C. brakeleyi and $C$. wirthi were attracted to calls of their host (Hyla spp.) in Georgia.

The present study indicates the likelihood of the females of Ur. macfarlanei, Ur. yaeymana, $M i$. luzonensis and $C$. nippon to be attracted to frog calls and feed on frog in nature. The biting activities of these flies may be nocturnal and they came to the speaker only at night. However, these nocturnal mosquitoes attracted to the frog calls may be hungry and often bite at day-time in the cage placed in a dark shed. It also indicates that this biting behavior 
may be more widespread in the genus Corethrella and some species of mosquito genera Mimomyia and Uranotaenia.

\section{ACKNOWLEDGMENTS}

We wish to thank Dr. Art Borkent, the Royal British Coloumbia Museum, Canada, for information related to our observations. We would like to thank Prof. Hidetoshi Ota of Tropical Biosphere Research Center, University of the Ryukyus, Dr. Masaya Tatara, Dr. Maki Okamura and Ms. Chieko Matsumoto of Iriomote Wildlife Center for their assistance in the field study. We are also grateful to Dr. Yong Hoi Sen for critically reviewing the manuscript.

\section{REFERENCES}

Bate, M. 1949. The Natural History of Mosquitoes. 399 pp. Macmillan, New York.

Clements, A. N. 1992. The Biology of Mosquitoes. Vol. 1. Development, Nutrition and Reproduction. 509 pp. Chapman and Hall, London.

Edwards, F. W. 1932. Genera Insectorum. Diptera. Family Culicidae. Fascicle 194, 258 pp. Bruxelles.

Kabaya, T. and Maeda, N. 2002. Frog-Tunes "In the Countrysides”. 48 pp. Yama-Kei Co. Books, Tokyo.

Lien, J. C., Lin, C. C. and Weng, M. H. 1998. A new record of Corethrella nippon Miyagi, 1980 from Taiwan (Diptera, Chaoboridae). Chinese J. Parasit., 11: 91-97.

Marks, E. 1960. Mosquitoes biting frogs. Aust. J. Sci., 23: 89 .

McKeever, S. 1977. Observations of Corethrella feeding on tree frog (Hyla). Mosq. News, 37: 522-523.

McKeever, S. and Hartberg, W. K. 1980. An effective method for trapping adult female Corethrella (Diptera: Chaoboridae). Mosq. News, 40: 111-112.

Miyagi, I. 1972. Feeding habit of some Japanese mosquitoes on cold-blooded animals in laboratory. Trop. Med. (Nagasaki), 14: 203-217.

Miyagi, I. 1974. On a blood-sucking Corethrella sp. collected in Nagasaki, Japan (Diptera: Chaoboridae). Trop. Med. (Nagasaki), 16: 89-93 (In Japanese).

Miyagi, I. 1975. A new species of the genus Core- thrella Coquillett from Japan (Diptera: Chaoboridae). Jpn. J. Sanit. Zool., 26: 25-29.

Miyagi, I. 1980. Notes on the Japanese species of the genus Corethrella, with the description of a new species (Diptera: Chaoboridae). Jpn. J. Sanit. Zool., 31: 15-21.

Miyagi, I. and Toma, T. 1980. Studies on the mosquitoes in Yaeyama Islands, Japan. 5. Notes on the mosquitoes collected in forest areas of Iriomotejima. Jpn. J. Sanit. Zool., 31: 81-91 (In Japanese with English summary).

Okudo, H., Toma, T., Sasaki, H., Higa, Y., Fujikawa, M., Miyagi, I. and Okazawa, T. 2004. A crab-hole mosquito, Ochlerotatus baisasi, feeding on mudskipper (Gobiidae: Oxudercinae) in the Ryukyu Islands, Japan. J. Am. Mosq. Control Assoc., 20: 134-137.

Remington, C. L. 1945. The feeding habits of Uranotaenia lowii Theobald (Diptera: Culicidae). Entomol. News, 56: 32-68.

Stone, A. 1956. Corrections in the taxonomy and nomenclature of mosquitoes (Diptera, Culicidae). Proc. Entomol. Soc. Washington, 578: 333-334.

Tanaka, K., Mizusawa, K. and Saugstad, E. A. 1979. A revision of the adult and larval mosquitoes of Japan (including the Ryukyu Archipelago and the Ogasawara Islands) and Korea (Diptera: Culicidae). Contrib. Am. Entomol. Inst. (Ann. Arbor), 16: 1-987.

Toma, T. and Higa, Y. 2004. A new species of Ficalbia (Diptera: Culicidae) from Iriomote Island, Okinawa, Ryukyu Archipelago, Japan. Med. Entomol. Zool., 55: 195-199.

Toma, T. and Miyagi, I. 1986. The mosquito fauna of the Ryukyu Archipelago with identification keys, pupal descriptions and notes on biology, medical importance and distribution. Mosq. Syst., 18: 1-109.

Toma, T., Miyagi, I. and Iha, S. 1983. Studies on the mosquitoes in Yaeyama Island, Japan. On the mosquitoes breeding around human dwellings in Ishigakijima and Iriomotejima. Jpn. J. Sant. Zool., 34: 99-101 (In Japanese with English summary).

Van Beurden, E. K. 1980. Mosquitoes (Mimomyia elegans (Taylor)) feeding on the introduced Toad Bufo marinus (Linneaus): implications for control of a Toad pest. Aust. Zool., 20: 501-504.

Williams, J. A. and Edman, J. D. 1968. Occurrence of blood meals in two species of Corethrella in Florida. Ann. Entomol. Soc. Am., 61: 1336. 